This PDF is a selection from a published volume from the National Bureau of Economic Research

Volume Title: Reforming the Welfare State: Recovery and Beyond in Sweden

Volume Author/Editor: Richard B. Freeman, Birgitta Swedenborg and Robert Topel, editors

Volume Publisher: The University of Chicago Press

Volume ISBN: 0-226-26192-1

Volume URL: http://www.nber.org/books/free05-1

Conference Dates: September 30-October 1, 2005

Publication Date: February 2010

Chapter Title: Policies Affecting Work Patterns and Labor Income for Women

Chapter Author: Ann-Sofie Kolm, Edward P. Lazear

Chapter URL: http://www.nber.org/chapters/c5359

Chapter pages in book: (57 - 81) 


\title{
Policies Affecting Work Patterns and Labor Income for Women
}

\author{
Ann-Sofie Kolm and Edward P. Lazear
}

\subsection{Introduction}

Taxes on labor income reduce the incentive for women to work. Child care subsidies, on the other hand, increase the incentive for women with children to work. Given the taxes on labor income, it may improve welfare to introduce subsidies or tax relief on substitutes for mothers' time in the household. However, ten years ago, Sherwin Rosen argued that the child care subsidies in Sweden were inefficiently high from a welfare perspective (Rosen 1997). He noted that the subsidy, in addition to encouraging labor supply, also distorts the consumption choice between child care services and other types of goods. By making the relative cost of child care services cheaper, the subsidy stimulates a socially excessive consumption of child care, at the expense of other types of goods. Finding the most efficient child care subsidy is a matter of balancing the distortion on the consumption mix with the tax-induced labor supply distortion (see Rosen 1997; Sorensen 1997; and Kleven 2004).

Ann-Sofie Kolm is an associate professor of economics at Stockholm University. Edward P. Lazear is the Morris Arnold Cox Senior Fellow at the Hoover Institution, the Jack Steele Parker Professor of Human Resources Management and Economics at the Graduate School of Business, Stanford University, and a research associate of the National Bureau of Economic Research.

Our work follows on that initiated by Sherwin Rosen. Sherwin was a truly insightful economist, who thought about economic issues deeply. His instincts were superb, and he had the ability to see the essence of the problem. His early work on Swedish family programs laid the groundwork for our thinking. We are indebted to him for inducing us to work on what is a very important issue, and we miss his continued guidance. In addition, we want to thank Birgitta Swedenborg, Richard Freeman, Annette Bergemann, Rickard Eriksson, Anders Forslund, Bertil Holmlund, Alan Krueger, Mats Persson, Nina Smith, Marianne Sundström, Bob Topel, and the seminar participants at the National Bureau of Economic Research/Center for Business and Policy Studies meetings in Boston and Stockholm. 
In this chapter, we analyze the effects of child care subsidies and other policies on female labor supply decisions in a life-cycle context that has not been fully considered in the previous literature. Our starting point is that a woman's labor market decision today may affect her standard of living later in life. Consider, for example, a married woman who chooses to devote all of her time to family and children, eschewing market work in the expectation that she will remain with her husband for her entire life. If her marriage dissolves, she will be without the skills necessary to earn a decent living in the labor market. Specializing in household production was the wrong decision. Even if women took into account the possibility of being single later in life, which would lead them to do some market work as insurance against the family breakup, those investing little in work skills who experienced marital breakup would end up poor and then may require social support. Knowing that social assistance will cushion the blow to women who find themselves without their husband's income, moreover, women will likely choose to work too little in the market from a social perspective. The implication is that previous analyses have understated the value of policies such as child care that are designed to encourage women to work.

We consider child care subsidies and three other policies that impact women's labor supply: paid parental leave, in-work benefits, and tax relief on substitutes for household goods and services. Child care subsidies and paid parental leave have long been studied as cornerstones of the Swedish welfare state, while the last two policies are relatively new, with little attention to their impact on women with children. Our measures of labor supply are labor force participation, work time, and time in parental leave, based on data from the labor force surveys. We develop a new model to examine the impact of the policies on the work outcomes, and we then link the model to observed behavior. We conclude by showing that policy instruments beyond child care subsidies could stimulate the labor supply of women with children as effectively as child care subsidies would, without inducing the overconsumption of child care services that troubled Rosen.

\subsection{Labor Supply of Women and Women with Children}

To begin, table 2.1 summarizes the employment patterns for women and men in Sweden, and by way of comparison, in the United States. In the developed world, Sweden's family policies are among the most generous, and the average tax rate and benefits when not working are among the highest, while the U.S. family policies, taxes, and benefits are among the lowest, giving us a sharp contrast.

The table shows that labor force participation among women is higher in Sweden than in the United States but that American women are more 
Employment patterns for men and women in Sweden and the United States, ages sixteen to fifty-four: 2005

\begin{tabular}{lccccc}
\hline & $\begin{array}{c}\text { Work hours/ } \\
\text { population }\end{array}$ & $\begin{array}{c}\text { Work hours/ } \\
\text { present workers }\end{array}$ & $\begin{array}{c}\text { Present workers/ } \\
\text { employed }\end{array}$ & $\begin{array}{c}\text { Employed/ } \\
\text { labor force }\end{array}$ & $\begin{array}{c}\text { Labor force/ } \\
\text { population }\end{array}$ \\
\hline Women (Sweden) & 19.0 & 33.3 & 0.81 & 0.94 & 0.78 \\
Women (United States) & 21.5 & 33.1 & 0.95 & 0.95 & 0.72 \\
Men (Sweden) & 26.1 & 39.3 & 0.87 & 0.93 & 0.82 \\
Men (United States) & 29.6 & 38.3 & 0.97 & 0.95 & 0.84 \\
\hline
\end{tabular}

Source: The labor force surveys, Arbetskraftsundersökningar (AKU) for Sweden, and the Current Population Survey (CPS) for the United States. The AKU went through some changes in 2005; see: www.scb.se. Note: The measures of average actual weekly work hours of those who are present at the workplace (column [2]) is based on the age group sixteen to sixty-four for Sweden and the United States. The work hours/present workers for the United States is based on March 2005 and not the yearly number.

likely to be at work at any given time. Multiplying the first column in table 2.1 by the total number of weeks per year, we calculate the annual average work hours in the two societies. The average annual work hours of women aged sixteen to fifty-four in Sweden is 988, compared to 1,118 in the United States. For women and men aged sixteen to fifty-four, average annual hours are 1,173 in Sweden and 1,329 in the United States. These numbers are comparable with what is reported in other studies (see Freeman and Schettkat 2005).

From the mid-1960s until the early 1990s recession, female labor force participation in Sweden increased dramatically. Since then, female participation has been stable, with only cyclical variations. In contrast, male labor force participation trended down modestly before the recession but has been stable, except for cyclical changes since the beginning of the 1990s. Women's labor force participation at 80 percent is almost as high as that of men at 85 percent.

Women with children have high rates of labor force participation in Sweden, although the rate is slightly lower for mothers with small children (figure 2.1). However, some of this difference may reflect different measurement protocols. Swedish statistics count women who are on paid parental leave from a job as employed. Because parental leave is popular in Sweden, with an average time on paid parental leave of ten months, and because fathers take a modest share of the family's paid parental leave (20 percent in 2006, up from 10 percent in 2000), this biases female participation upward relative to that in the United States. For a better comparison, we need to redefine women on parental leave as being out of the labor force in Sweden. As that is not possible in the aggregate labor force survey data, we treat all women who have children below one year of age as being on parental leave and out of the labor force. This is crude but realistic, as more than 80 percent of mothers who have a child younger 


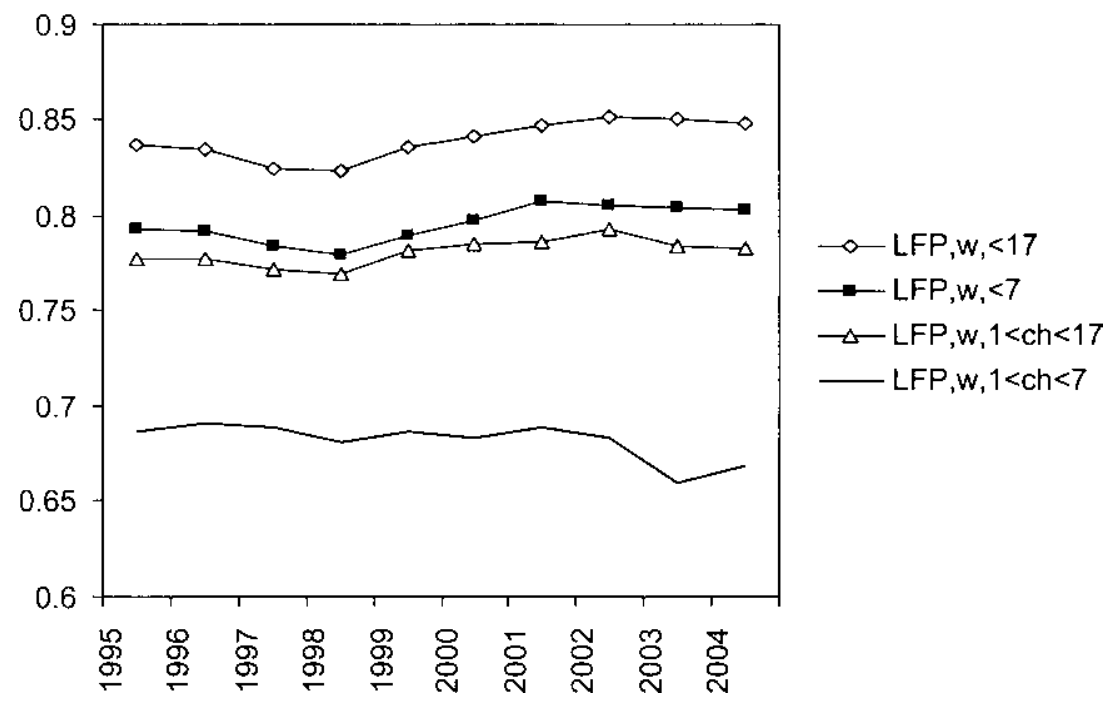

Fig. 2.1 Labor force participation rate (labor force/population; LFP) for women with children (children less than seventeen years old) and for women with small children (children less than seven years old)

Source: The labor force surveys (AKU), Statistics Sweden.

Note: The two lower graphs account for women with children below one year who are on parental leave and defined as out of the labor force.

than one year old are not present at the workplace during the week of measurement. ${ }^{1}$ Figure 2.1 reveals that this correction substantially reduces participation rates.

Parental leave is one reason to be absent from work, but there are also other reasons, such as vacation, sick leave, sick children, and so forth. Figure 2.2 shows the employment rate and the rate of presence at the workplace for women with children. Counting only women who were present at the workplace sometime during the week of measurement, the rate falls to around 50 percent for mothers with small children.

Finally, table 2.2 shows that even if we assume that all women in Sweden who have a child younger than one year of age are on parental leave and are counted as being out of the labor force, women with children have higher labor force participation in Sweden than in the United States. There is a real behavioral difference in the differing participation of women with children in the United States and Sweden.

1. Moreover, we know that mothers take an average of about ten months of paid parental leave (Ekberg, Eriksson, and Friebel 2005). Additionally, we know that mothers tend to lengthen their maternity leave by using the low flat rate paid parental leave (Westerlund, Lindbald, and Larsson 2005). 


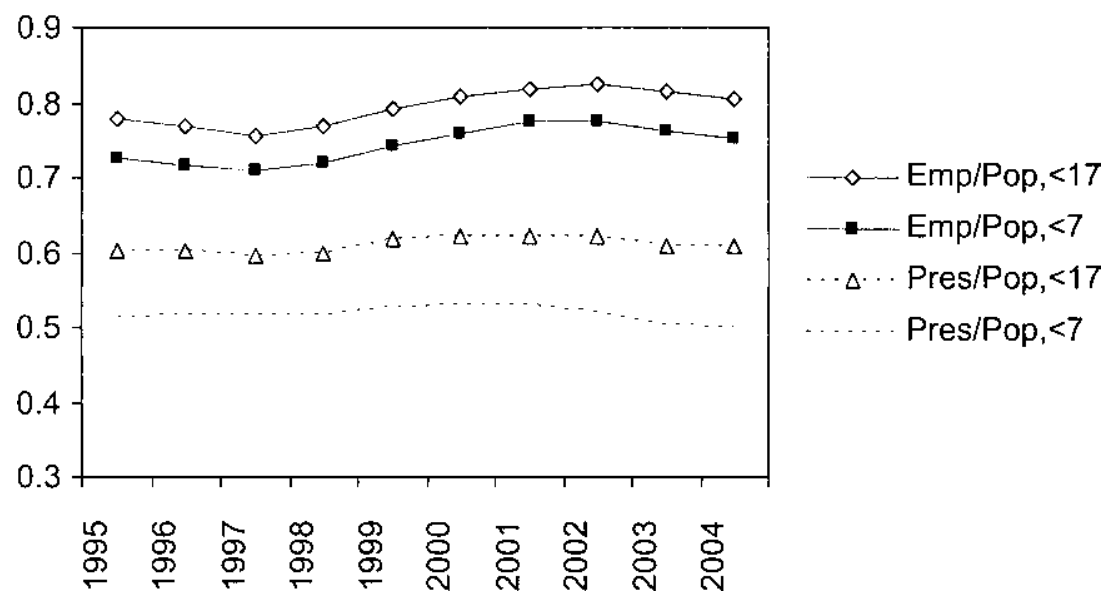

Fig. 2.2 Swedish female employment and presence at the workplace relative to population by category

Source: The labor force surveys (AKU), Statistics Sweden.

Table 2.2

Labor force participation as percent in labor force of women and men (ages sixteen to sixty-four) by age of youngest child in household in Sweden and the United States: March 2005

\begin{tabular}{lccccc}
\hline & $\begin{array}{c}\text { With child } \\
\text { age }<17\end{array}$ & $\begin{array}{c}\text { With child } \\
\text { age }<7\end{array}$ & All & $\begin{array}{c}\text { With child age } \\
<17 \text { and }>1\end{array}$ & $\begin{array}{c}\text { With child age } \\
<7 \text { and }>1\end{array}$ \\
\hline Women (Sweden) & 84 & 81 & 74 & 78 & 67 \\
Women (United States) & 71 & 63 & 69 & - & - \\
Men (Sweden) & 93 & 94 & 78 & - & - \\
Men (United States) & 94 & 96 & 81 & - & - \\
\hline
\end{tabular}

Source: The labor force surveys, the CPS (United States), and AKU (Sweden).

Note: The first two columns show the labor force participation rate (labor force/population) for women and men with children (children less than seventeen years old for Sweden and less than eighteen years old for the United States) and for women and men with small children (children less than seven years old in Sweden and less than six years old in the United States). The fourth and fifth columns assume that women with children below one year of age are on parental leave and are defined as out of the labor force. Dashed cells $=$ not applicable.

\subsubsection{Working Time}

Women are less likely to work full-time than men, and women with children, especially those with small children, are less likely to work full-time than those without children (see figure 2.3). Comparing Sweden and the United States, table 2.3 indicates that women with children work less than women without children in both countries, while table 2.4 shows a similar pattern in hours worked per week. To see whether the lower work time of 


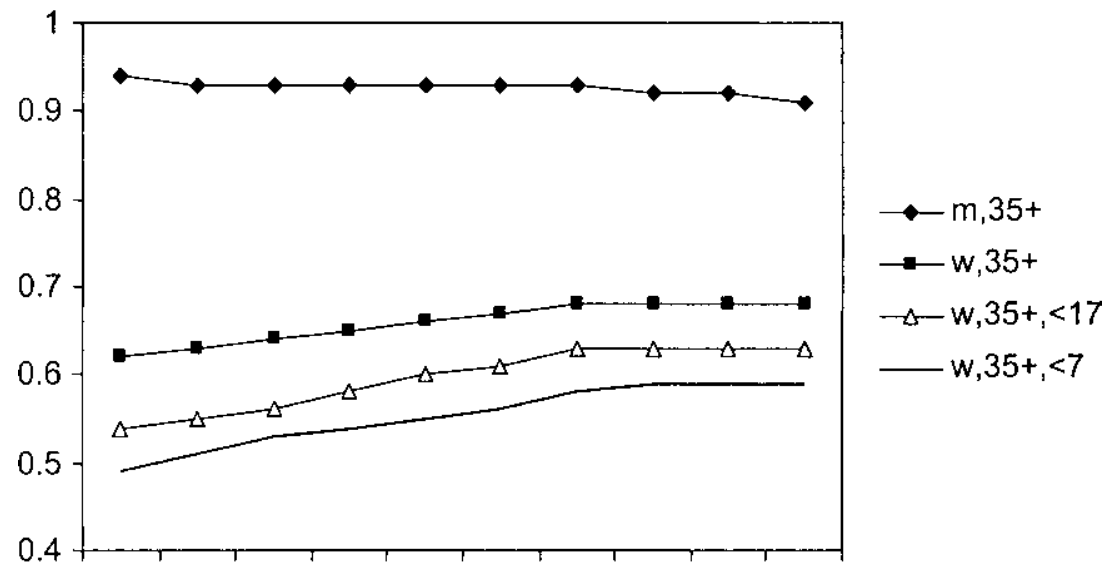

1995199619971998199920002001200220032004

Fig. 2.3 The share working more than thirty-five hours a week for men, women, women with children less than seventeen years old, and women with children less than seven years old

Source: The labor force surveys (AKU), Statistics Sweden.

Table 2.3 Percentage of persons working part-time in total employment by category: 2004

\begin{tabular}{lccccccccc}
\hline & \multicolumn{4}{c}{ Women } & & \multicolumn{3}{c}{ Men } \\
\cline { 2 - 4 } & $\begin{array}{c}\text { No } \\
\text { children }\end{array}$ & One child & $\begin{array}{c}\text { Two or more } \\
\text { children }\end{array}$ & Total & $\begin{array}{c}\text { No } \\
\text { children }\end{array}$ & $\begin{array}{c}\text { With } \\
\text { children }\end{array}$ & Total \\
\hline Sweden & 14.6 & 16.7 & 22.2 & 17.9 & & 5.2 & 3.4 & 4.3 \\
United States & 10.1 & 15.8 & 23.6 & 14.6 & & 3.5 & 1.8 & 2.7 \\
\hline
\end{tabular}

Source: Women at Work: An Economic Perspective (Boeri, Del Boca, and Pissarides 2005).

women with children is due to mothers reducing their working time, it is necessary to use microdata. Kennerberg (2007) does this, comparing the working time of women before and after they have a child to their childless counterparts. Prior to childbirth, 90 percent of women worked in a full-time job, just as women without children did. After the birth of the first child, about 10 percent of mothers reduced their work time when returning to work after their parental leave, whereas women who did not have a child increased their work time slightly over the same period.

While women are more likely to work part-time after having children, the reverse is true for men. This suggests that there is some substitutability of males for female work time and/or that men with children feel more compelled to earn instead of taking leisure. Selection into marriage could also be an explanation, as men who are likely to be part-timers may not get married 
Table 2.4

Female and male actual average weekly work hours among those who worked in Sweden and the United States, ages sixteen to sixty-four: March 2005

\begin{tabular}{lc}
\hline & Actual work hours \\
\hline Sweden & 31.2 \\
Women & 28.7 \\
Women with child age $<7$ & 36.5 \\
Men & 36.5 \\
Men with child age $<7$ & \\
United States & 33.1 \\
Women & 30.6 \\
Women with child age $<6$ & 38.3 \\
Men & 41.5 \\
Men with child age $<6$ & \\
\hline
\end{tabular}

Source: The labor force surveys, AKU (Sweden), and the CPS (United States).

Note: The numbers are average hours worked in preceding week for the U.S. sample. In Sweden, they are the actual hours worked among those who worked.

to the same extent as others. We do not know of any longitudinal study that differentiates these effects for men.

\subsubsection{Work Incentives and Single Women with Children}

The work behavior of single women with children is also important in female labor supply and in the level of poverty. Families with a single female parent and no male parent are disproportionately represented in poverty. In countries where female labor force participation is high, the share of poor among single mothers is also relatively low. ${ }^{2}$ What are the incentives to work for single women with children? How responsive is this group to incentives?

An important measure of work incentives is the replacement rate when not working. In most countries, this replacement rate is higher at lowerincome levels, where single mothers are overrepresented. For Sweden, Flood, Pylkkänen, and Wahlberg (2007) calculate the average replacement rate for single mothers on social assistance in 1999 to be 91 percent for a half-time job and 79 percent for a full-time job. Andrén (2003) and Flood, Pylkkänen, and Wahlberg (2007) have estimated structural static models of labor supply for single mothers that suggest that Swedish single mothers do respond positively to increased returns to work. Moreover, the labor supply elasticities are significantly larger for single mothers than for other groups. Flood, Hansen, and Wahlberg (2004) estimate a structural static model of household labor supply to capture labor supply among two-parent families in Sweden. We summarize in table 2.5 the estimated elasticities. 
Table 2.5

The labor supply elasticity of single mothers, women, and men in Sweden

\begin{tabular}{cccc}
\hline & Single mothers & Women & Men \\
\hline Labor supply elasticity & $0.62-0.77^{\mathrm{a}}$ & $0.1^{\mathrm{b}}$ & $0.05^{\mathrm{b}}$ \\
\hline
\end{tabular}

aFlood, Pylkkänen, and Wahlberg (2007) and Andrén (2003).

${ }^{b}$ Flood, Hansen, and Wahlberg (2004).

\subsubsection{Fertility}

In the 1950s through the 1970s, countries with high fertility had low rates of labor participation for women, but in the 1980s through the 1990s, this pattern reversed itself. Sweden and the United States, in particular, combined high rates of female participation with high fertility for an advanced country (figure 2.4). During the crisis years in the beginning of the 1990s, the fertility rate in Sweden dipped, but the rate is still high and has begun to catch up to its old levels. Figure 2.4 records the total fertility rate for Sweden and the United States. Because Sweden's large welfare state requires tax revenues from a working population, combining work and fertility may be more important for Sweden's success than for that of the United States.

\subsection{Policies that Affect Participation of Women with Children}

We consider next the four welfare state policies that are most relevant to the participation of women with children.

\subsubsection{The Paid Parental Leave System}

Since 1955, employed Swedish women have had the right to paid maternal leave by way of the social insurance system. Table 2.6 provides a description of the parental leave scheme since 1995. In 1974, Sweden became the first country to replace the maternity leave system with a parental leave system, where the same rules for fathers and mothers applied. Parental leave initially covered six months of payment, but it was gradually extended over the years to cover fifteen months by the year 1990. In 1993, parents shared 360 days, with a compensation corresponding to 90 percent of gross earning up to a ceiling and another ninety days at the guaranteed flat rate of sixty Swedish kronor (SEK) per day.

The Swedish parental leave system is unique in terms of generosity and flexibility. Government expenditures on paid parental leave is about 17 billion SEK, or about 0.7 percent of gross domestic product (GDP). Parents have the legal right to take parental leave for up to eighteen months without the risk of losing their jobs. Parents can use their days of paid parental leave in a flexible way until the child becomes 8 years old. In addition, parents have the legal right to reduce their working time to 75 percent of a normal work week at the workplace until the child turns 8 years old. In 1995, the 


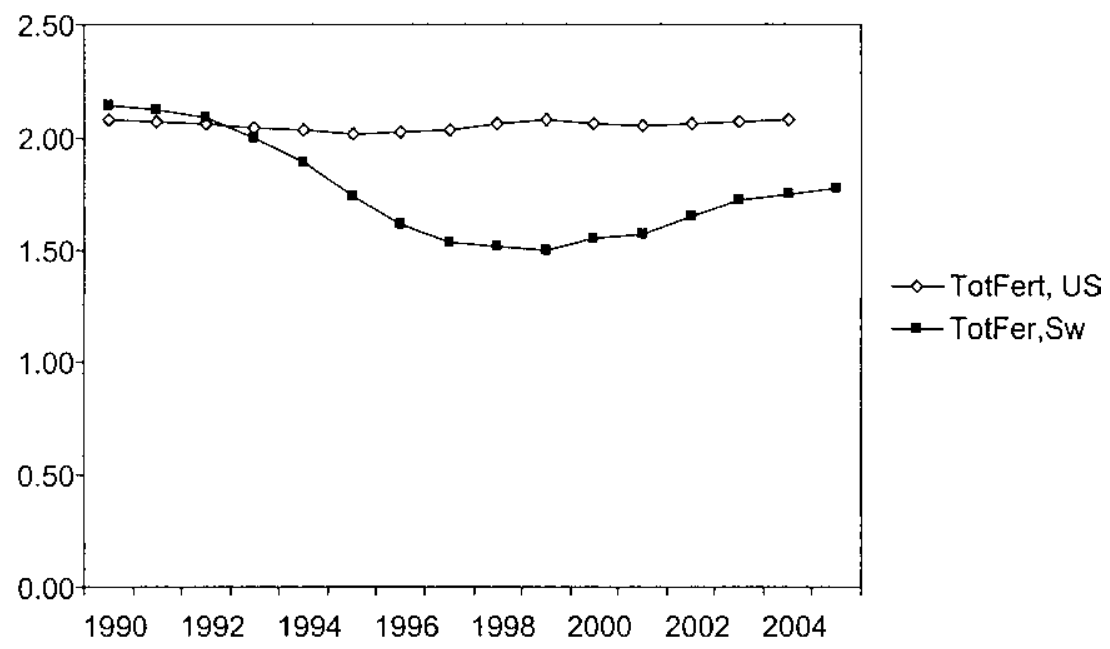

Fig. 2.4 Total fertility rates for Sweden and the United States

Table 2.6 The parental leave scheme

\begin{tabular}{lcccccc}
\hline Year & $\begin{array}{c}\text { Total } \\
\text { days }\end{array}$ & $\begin{array}{c}\text { Reserved/ } \\
\text { parent }\end{array}$ & Duration & $\begin{array}{c}\text { Replacement } \\
\text { rate }(\%)\end{array}$ & $\begin{array}{c}\text { Ceiling } \\
(* \text { PBA })\end{array}$ & PBA \\
\hline 1995 & 450 & 30 & 360 & 80 & 7.5 & 35,700 \\
1996 & 450 & 30 & 360 & 75 & 7.5 & 36,200 \\
1997 & 450 & 30 & 360 & 75 & 7.5 & 36,300 \\
1998 & 450 & 30 & 360 & 80 & 7.5 & 36,400 \\
1999 & 450 & 30 & 360 & 80 & 7.5 & 36,400 \\
2000 & 450 & 30 & 360 & 80 & 7.5 & 36,600 \\
2001 & 450 & 30 & 360 & 80 & 7.5 & 36,900 \\
2002 & 480 & 60 & 390 & 80 & 7.5 & 36,900 \\
2003 & 480 & 60 & 390 & 80 & 7.5 & 38,600 \\
2004 & 480 & 60 & 390 & 80 & 7.5 & 39,300 \\
2005 & 480 & 60 & 390 & 80 & 7.5 & 39,400 \\
$2006^{\mathrm{a}}$ & 480 & 60 & 390 & 80 & 10 & 39,700 \\
2007 & 480 & 60 & 390 & 80 & 10 & 40,300 \\
2008 & 480 & 60 & 390 & 80 & 10 & 41,000 \\
\hline
\end{tabular}

Source: Bergemann and van den Berg (2006) and information from publications of the National Social Insurance Board. See: http://www.forsakringskassan.se/.

Note: The daily flat compensation for the ninety days has been 60 SEK from 1995 to 2005 and 180 SEK from July 1, 2006. The price base amount (PBA) is a yearly adjusted amount used, among other things, to ensure that various benefits do not decline in value because of an increase in the general price level (inflation).

${ }^{a}$ The ceiling was raised for children born after July 1, 2006. 
government introduced the so-called daddy month, which required one month of the paid parental leave to be used by each parent. In practice, fathers could no longer transfer all their paid parental leave to the mother. Unless at least one month was used by the father, it could not be used by either parent. In 2002, a second father quota was implemented. The reform reserved two months for each parent. At the same time, the total time of entitlement to paid parental leave for the family increased by thirty days. In practice, this implied that an extra month available only for fathers was added to the existing paid parental leave scheme.

\subsubsection{Child Care Subsidies}

Publicly provided child care was introduced in the mid-1960s. The pressure on municipalities to provide day care became larger in the mid-1970s, and by 1983, publicly provided day care covered 52 percent of preschool children. By 2004, over 80 percent of preschool children were in public day care, and nearly 80 percent of children aged six to nine years were enrolled in after-school centers.

Gradually increasing fees for child care in the 1990s and differences in fees across municipalities led the government to impose a ceiling on fees, the maximum fee system, in 2002. The reform fixed the fees for child care at a certain percent of parental income and specified a maximum cost to the household. ${ }^{3}$ The maximum fee system reduced differences in fees across municipalities and cut the child care fee for most families. The share of child care costs covered by private fees fell from around 20 percent to around 10 percent.

From 2001 to 2003, the program was expanded to allow the children of parents who were unemployed and on parental leave the right to attend preschool at least fifteen hours per week. Universal preschool for four- and five-year-olds was also introduced. Although preschool is not compulsory, the municipalities are obliged to provide places in preschool for the children of parents who wish it.

The average cost per child in preschool was almost 96,000 SEK in 2004. The total cost for preschool in 2004 was about 34 billion SEK, or about 1.3 percent of GDP.

\subsubsection{In-Work Benefits}

Following the lead of the United States and the United Kingdom, many industrialized countries have adopted some kind of in-work benefit ${ }^{4}$ - a ben-

3. In 2005 , the child care fee for a family with one child in day care was 3 percent of family income, with a maximum fee of 1,260 SEK per month. The fee for the second child was 2 percent of family income, with a maximum fee of 840 SEK per month. For the third child, the fee was 1 percent of family income, with a maximum fee of 420 SEK a month. There was no fee for the fourth child.

4. Belgium, Canada, Denmark, Finland, France, Ireland, the Netherlands, and New Zealand now have such systems. 
efit or tax credit conditioned on labor income that aims to improve work incentives and reduce poverty. In January 2007, Sweden also introduced a system of in-work benefits in the form of a tax credit for the employed. The tax credit became more generous in January 2008 and January 2009. The tax credit, in combination with a general income tax allowance, implies that no tax needs to be paid on labor income up to yearly earnings of about 39,000 SEK. This can be compared to the median income, which is about 220,000 SEK per year. Then, about 25 percent of labor income earned on top of this limit is tax exempt, until a yearly income level of 116,000 is reached. For income above this limit, only about 6.5 percent of labor income is tax exempt. The maximum tax allowance is reached when the yearly labor income is about $300,000 \mathrm{SEK}$. The maximum tax credit amounts to about 18,000 SEK per year. The credit is not phased out, and it is more generous for workers above age sixty-five.

\subsubsection{Tax Relief for Household Substitutes}

A number of countries in Europe-Austria, Belgium, Denmark, Finland, and France - have introduced systems of subsidies or tax relief on the purchase of substitutes for household services. After a long debate, in July 2007, Sweden introduced the benefits of tax relief on household services, including house cleaning, laundry, ironing, gardening, and babysitting. As long as the service is carried out within the home, half of the labor costs of the substitute labor up to a ceiling is deductible from the income tax payments of the buyer.

\subsection{A Model of Female Work Behavior}

How have Sweden's family policies in the form of parental leave and child care subsidies affected women's labor supply and their economic situation? How might the more recent changes of in-work benefits and tax relief for household services affect these outcomes?

We examine these questions in the context of a small theoretical model of female decision making. This section gives a nontechnical presentation of the model and summarizes the main results. The appendix contains details.

The model is set in two periods. In the first period, women are married. In the second period, there is an exogenous probability that the marriage dissolves. At the beginning of the first period, the woman makes her career choice: allocating available time into market work and family work. As the allocation of time also has consequences for the future, she takes into account the possibility that the marriage may dissolve in period two when making her period-one time allocation decision. Viewing labor supply in the first period as an investment, we let the woman's labor supply in the first period also determine her supply in the second period. This assumption captures the fact that the decision to choose a weak labor market attachment early in life is likely to induce a lower income in the future. 
Women derive utility from general goods consumption and from the consumption of a family good. The family good can be produced in the household by the use of own time, or it can be purchased in the market. These are perceived to be substitutes, although not necessarily at a one-to-one ratio. The payoff from investing time in the family is the utility the home-produced family good yields. The payoff from investing time in market work is market income net of taxes. We use the model to predict consequences of changing each of the four policies described in section 2.3 for the behavior or poverty of women with children.

\subsubsection{Paid Parental Leave}

Increased generosity in paid parental leave should reduce women's investment in a more market-oriented career. This is because there is a direct negative effect on market investment when the payments for family time increase. In addition, the increased taxation that funds the leave will have a negative effect on work incentives. We expect poverty among divorced women to increase, because women should invest more in a family-oriented career, and because the reform requires higher taxes.

The effect of the first daddy-month reform in 1995, which cut the leave time for mothers, depends on whether mothers choose to exhaust the paid parental leave periods. The reform is more likely to increase female labor supply if women exhaust their leave periods. The second daddy-month reform in 2002 added an extra month of parental leave, which, in practice, was only available for fathers. Counterintuitively, this tends to reduce women's investment in market-oriented careers. The reason is that an increase in the father's time at home increases the female spouse's consumption of the family good, which induces her to buy less care time on the market. In fact, she reduces her market purchases of the family good by more than the father's increased contribution. The reason for this is that the reform needs to be financed. An increase in the paid home time for fathers requires increased tax rates to finance the reform, which reduces the incentives to supply market work. Therefore, female market work is reduced, which implies that she works more in the household in response to the father's increased contribution of the family good. The marginal care of children is provided by market-supplied child care rather than by the mother, whose time is inframarginal. It is the father's time that substitutes for market purchases of child care- not for the mother's time. The reduction in market demand for child care, coupled with the tax effect, causes female market time to decline with the second reform. Poverty among divorced women increases, both because women invest more in family-oriented careers, and because the reform requires higher taxes.

\subsubsection{Child Care Subsidies}

Introducing a child care subsidy should increase women's time in the market and reduce poverty among divorced women, provided women finance 
a minor share of the government expenditures on the child care subsidy. The opposite holds when women must finance a major part of the subsidy. Furthermore, the ceiling on fees has a positive effect on labor supply. This is because the dampening effect on labor supply is removed when the fee no longer increases with income. Thus, women invest more in market-oriented careers in case the child care fee is uniform and fixed instead of income related. However, for low-income families, the negative effect of incomedependent fees remains. Moreover, such a reform increases the welfare gap between married and divorced women. This follows, as a ceiling reduces the fee for high-income earners relative to low-income earners.

\subsubsection{In-Work Benefits}

The model yields the following result: if women finance a minor share of the government expenditures on the in-work benefit, a steeper phase-in profile increases women's time in the market, reduces poverty among divorced mothers, and reduces the welfare gap between married and divorced women for women in the phase-in region. If women finance a major share of the inwork benefit, the effect is ambiguous. When women can transfer the burden of financing the in-work benefit to other citizens, the direct effect of the benefit dominates the tax effect, and women will invest more time in the market. The poverty among divorced women falls, both because women choose more market careers, and because the in-work benefit increases.

The more generous in-work benefit, which is only available to divorced women in the model, will reduce the dispersion in well-being between married and divorced women. This follows because the in-work benefit directly increases the income of divorced women, and because labor income increases as women invest more in market-oriented careers.

A steeper phase-out range has an ambiguous effect on market investments, poverty, and welfare dispersion for women in the phase-out region.

\subsubsection{Household Substitutes}

If the market for household substitutes is small, introducing a price subsidy on the purchased household goods will induce women to invest more in market careers and to consume more household goods; it will also reduce poverty among divorced women and reduce the welfare gap between married and divorced women.

A subsidy reduces the price of the market-produced household goods, increasing total consumption of household goods. As market-purchased goods become relatively cheaper, the amount of household goods bought from the market increases, at the expense of home-produced household goods. Thus, women will invest more in market-oriented careers, as they find it optimal to substitute household goods produced by own time for marketproduced household goods. This is the distortion that Rosen focused on in the context of market-provided child care. But higher market investments 
also improve women's economic situations in case of divorce, thus reducing poverty among divorced women.

In addition, subsidizing market-provided household goods reduces the welfare difference between married and divorced women, even though one assumes that only married women buy the subsidized household service. The primary effect of subsidizing market-provided household goods is to induce women to invest more in labor market skills during the investment years. This has more value to women who eventually divorce than to married women. Married women work more after the investment period than they would in the absence of the subsidy, but most of that income merely replaces household production with market production. Although there is a small increase in welfare from using the cheaper technology to produce the same goods (and therefore to consume more total goods), most of the income nets little gain, because it merely allows technology substitution. Divorced women use the incremental income to purchase additional goods rather than to produce the same goods with a different technology. As a result, the gain to divorced women from the additional labor supply is first order, whereas the gain to married women is second order. This narrows the gap in welfare between married and divorced women.

At the same time, the tax increases needed to subsidize the household substitutes imply higher taxes on work. This in turn discourages women from investing in market-oriented careers. This effect, however, will be small when the market for household goods is small. Then, the cost of financing the subsidy and the required tax increase will be low, implying a modest adverse impact on women's investment in market work.

\subsection{Linking the Model of Policy Effects to Work Patterns and Labor Income for Women}

Having described the employment patterns of women (section 2.2) and having developed a theoretical model to determine how women's labor market outcomes can be linked to the four policies in focus (section 2.4), we now examine the relation between the patterns and the model.

\subsubsection{Paid Parental Leave}

The generous duration and levels of parental leave payments in our model are the most likely factors explaining the long time spent in maternity leave in Sweden. This view is supported by empirical evidence (Pylkkänen and Smith 2004), which shows that a higher compensation rate during parental leave prolongs the break from market work. Mothers in Sweden take an average of ten months off for paid maternity leave.

It is likely, moreover, that the right to paid parental leave, combined with the legal right to return to previous employment, explains some of the high participation rate among mothers in Sweden (even when all mothers with 
children below the age of one are counted as out of the labor force; see table 2.2). This is consistent with empirical research. Ruhm (1998), using data for nine European countries over the period from 1969 to 1993, found that the right to paid leave raises the percentage of women employed by between 3 and 4 percent. Only about one-quarter of this effect can be attributed to an increase in women who are registered as employed but are absent from work due to the parental leave program. Ruhm offers two explanations. First, women who would otherwise choose not to participate may search for a job in order to qualify for the paid parental leave scheme. (Because parental leave is disproportionately enjoyed by women but is paid for by men, the policy raises the value of work for women.) Second, the scheme may speed up the reentry to work. The reason is that some mothers who would have quit their jobs to take a long leave period now find it worthwhile to return to work sooner in order to remain in their old job. In the Swedish case, Ronsen and Sundström (2002) find that the right to paid parental leave, coupled with the legal right to return to their previous jobs, speeds up the return to employment for women. However, once these rights exist, prolonging the maternity leave period and extending the right to it may reduce labor supply, as it prolongs the time in parental leave. This suggests that a slightly less generous parental leave scheme - in terms of payment and duration - would increase female labor supply — in terms of a shorter maternity leave - without inducing women to drop out of the labor force.

The Swedish parental leave scheme provides parents with the legal right to reduce their work time to 75 percent of a full-time job (at their full-time hourly wage) until the child is eight years of age. This rule encourages less work hours but most likely contributes to higher labor force participation. Cross-country analyses have shown that there is a positive link between parttime job opportunities and female labor force participation (see Del Boca and Pasqua 2005). Thus, the legal right to reduce work time from full-time to part-time may have a positive effect on the participation decision but a potentially negative effect on the intensity decision.

Consistent with our theoretical analysis, the empirical evaluations of the daddy-quota reforms (Ekberg, Eriksson, and Friebel 2005; and Eriksson 2005) indicate that the first daddy-quota reform increased women's labor supply, whereas the second reform reduced it. See table 2.7 for a comparison of the use of parental leave days before and after each daddy-quota reform. This suggests that the second reform, which restricted the number of transferable months and extended the total family leave time, was not successful from a female labor supply perspective.

The parental leave system probably affects the wages of women relative to men. As parental leave is mainly used by mothers, the program may reduce human capital of women relative men, which may affect earnings differentials. Of course, this does not imply that the women are worse off with the program than without it. 
Table 2.7

Mean number of parental leave days for the first and second daddy-month reforms: the first seventeen months

\begin{tabular}{lrrrrrr}
\hline & \multicolumn{2}{c}{1995 reform } & & \multicolumn{2}{c}{2002 reform } \\
\cline { 2 - 3 } \cline { 5 - 6 } & Before & After & & Before & After \\
\hline Father & 23 & 28 & & 31 & 34 \\
Mother & 311 & 286 & & 259 & 264 \\
\hline
\end{tabular}

Source: Eriksson (2005). The total family parental leave days with an income-based payment in 1995 and 2002 are 360 and 390, respectively.

Note: Note that the number of parental leave days in this table is measured seventeen months after the birth. We know that fathers use their parental leave days to a larger extent when the child is older, which tends to underestimate the number of parental leave days the father is using, as well as his share of the total days (see Eriksson 2005).

Datta Gupta, Smith, and Verner (2006) discuss how a differentiated takeup rate of parental leave may induce a high personal penalty for fathers who take leave. They argue that mothers may be induced to select into relatively low-paid jobs in the public sector, where it is easy to combine a career with family and where the personal penalty of leave is especially low, whereas men sort into the private sector and become the family breadwinner. They also argue that the large employment opportunities in the public sector, which supply particularly generous and flexible parental leave schemes, may have induced gender-segmented labor markets in the Nordic countries (see also Albrecht, Edin, and Vroman 1999).

\subsubsection{Child Care Subsidies}

Studies of the effects on labor supply of child care policy find that high availability and subsidized fees tend to increase female labor supply. The size of the effects, however, is less clear (Jaumotte 2003). A study of the access and price of child care in Denmark found that availability had a positive effect on female labor supply, whereas higher fees had a negative effect (Simonsen 2005). Domeij and Klein (2008), in a calibrated dynamic life-cycle model for Germany, show that the labor supply of mothers with small children would be large if Germany expanded the availability of highly subsidized child care.

But Sweden appears to be an outlier in this respect. An evaluation of the Swedish child care fee reform of 2002 did not find that the reform significantly affected female work hours and participation (Lundin, Mörk, and Öckert 2007). A possible interpretation is that although child care subsidies have historically played an important role for female labor supply by reducing the costs of working, further increases in an already-high subsidy may have only marginal effects on mothers' labor supply. If true, this suggests that a reduction in the child care subsidy would not cause major dropout from the labor market. 


\subsubsection{In-Work Benefits}

In-work benefits have only recently been implemented in Sweden, so we rely on theory and experiences in other countries to suggest the directions and size of effects.

The United States introduced the earned income tax credit (EITC) more than thirty years ago and has expanded it significantly since then. The EITC is now the largest cash transfer program at the federal level for low-income families. In 2003, about 20 million families received a total of $\$ 34$ billion in benefits from it. The EITC is targeted toward low-income families with children. The largest group receiving the in-work benefit is single mothers. ${ }^{5} \mathrm{It}$ has a phase-in region, where the size of the tax credit is given as a proportion of earned income. Once the maximum EITC is reached, the credit is held fixed at its maximum level until the phase-out region starts. The tax credit is eventually phased out completely. ${ }^{6}$

Evaluations of the EITC in the United States draw quite a positive picture of the impact of the EITC on labor supply. Eissa and Liebman (1996) compared the labor supply responses of single women with children to the responses of single women with no children when the earned income tax credit expanded in 1986. They showed that between 1984 to 1986 and 1988 to 1990 , single women with children increased their relative labor force participation by up to 2.8 percentage points. Meyer and Rosenbaum (2001) found that 63 percent of the increase in labor force participation of single families in the United States between 1984 and 1996 was due to the expansion of the EITC. The participation decision rather than the hour decision appears most influenced by the EITC. ${ }^{7}$

Will this type of policy have a similar effect in Sweden and in other less market-oriented economies as in the United States? Kolm (2008) provides a discussion of an earned income tax credit in a Swedish context. Simulation studies that take account of European institutional settings when estimating the effect of in-work benefits on labor market performance suggest that this will be the case. Although the Swedish tax credit is slightly different than the U.S. one and is not targeted specifically toward single mothers, the

5. See Eissa and Hoynes (2006).

6 . For the year 2006 (tax year 2005), income must have been less than $\$ 35,263$ ( $\$ 37,263$ married filing jointly) with two or more qualifying children; less than $\$ 31,030$ ( $\$ 33,030$ married filing jointly) with one qualifying child; or less than $\$ 11,750$ (\$13,750 married filing jointly) with no qualifying children. The maximum credits are $\$ 4,400$ with two or more qualifying children; $\$ 2,662$ with one qualifying child; or $\$ 399$ with no qualifying children. Available at: www.irs.gov/eitc.

7. The drawback with a tax credit of the EITC type is that the increased marginal tax rates in the phase-out region might create disincentives to work for those already in the labor market. The evaluations of the EITC seem to show that these effects exist but that the magnitude is small. The EITC also tends to reduce incentives to enter the labor market for secondary family earners. Eissa and Hoynes (2004) show evidence for such an effect, but again, the effect seems to be small. 
empirical evidence of the labor supply elasticity of single mothers reviewed earlier suggests that they are likely to respond to improved work incentives in the desired direction.

\subsubsection{Tax Relief on Household Substitutes}

This policy is also so recent in Sweden that we have to rely on the experience of other countries. Our model exercise suggests that tax relief on household substitutes enables women to work more in the labor market, as they can substitute market-purchased household services for own household time. It improves welfare to introduce subsidies or a tax relief on household substitutes, child care being the most significant example. Sketchy evaluations of the systems in other countries show that the policies appear to increase employment. However, more careful empirical evaluations are needed in order to clarify the contributions of these policies.

It also may be important to have access to a market for household substitutes. Freeman and Schettkat (2005) propose this as an explanation for much of the EU-U.S. employment and hour differences that are observed. They argue that in the United States, there has been a more extensive shift of traditional household production - food preparation, child care, elderly care, house cleaning - to the market than in Europe. However, Sweden differs from the EU average in some important ways. When it comes to child care, the generous child care subsidies in Sweden have induced an extensive shift of child care from the household to the market sector. Freeman and Schettkat (2005) present numbers on the percentage of children under the age of three enrolled in formal day care. In Sweden, 48 percent use formal day care, whereas the number is 54 percent in the United States; the European average is 29 percent. But markets for other types of household services are either nonexistent or relatively small in Sweden. Swedes spend about 7.7 hours a week cooking at home, whereas U.S. citizens spend only about 4.1 hours a week cooking at home (see Freeman and Schettkat 2005).

Detailed time-use data for Sweden and the United States show that women spend more time cooking, cleaning, and so forth than women in the United States. Employed women in Sweden allocate thirteen hours a week on such tasks, compared to ten hours for women in the United States. The corresponding numbers for men are almost seven hours for Sweden and a bit over three hours for the United States. Employed women in the United States, however, do work more in the market and consume less leisure than Swedish women. The same pattern holds for men.

High taxes and relatively high wages at the lower end of the wage distribution make household substitutes expensive in Sweden. The child care subsidy is one notable exception that is pushing in the direction of increased labor supply, and the question is whether tax relief on household substitutes can further increase women's attachment to the labor market, as suggested by our model. It probably can. 


\subsection{Conclusion}

This chapter has linked the distinctive features of the labor supply of Swedish women, particularly those with small children, to Swedish family policies - especially the paid parental leave system and the child care subsidies. Based on our theoretical framework, as well as on previous theoretical and empirical research, we conclude that the Swedish flexible parental leave system, with its generous legal rights to return to the previous employer and its heavily subsidized day care, helps explain the high labor force participation rate among women with children. However, the generosity of the paid parental leave system, in terms of payment and duration, also most likely explains why we observe such long career breaks for women following childbirths in Sweden. In addition, the two daddy-quota reforms that were carried out in 1995 and 2002, respectively, seem to have encouraged fathers to take longer parental leave but have not induced mothers to work moreat least not the 2002 reform.

Returning to Rosen's analysis of the Swedish child care subsidies from an efficiency viewpoint with which we began, a natural concluding question is, could child care subsidies be replaced by another policy instrument that can stimulate the labor supply of women with children, without distorting the consumption mix in favor of child care services? Our answer is yes.

The subsidized child care in Sweden, which is available only to employed parents, can be viewed as an in-work benefit. ${ }^{8}$ As the mother is usually the primary caretaker and thus the last person to leave the household for a job, the child care subsidy can be expected to have a qualitatively similar positive effect on her labor force participation as would a tax credit on earned income. $^{9}$

Child care subsidies affect labor force participation positively, as does an in-work benefit, but the child care subsidy is in kind. It distorts consumption in favor of child care, as Sherwin Rosen pointed out. An alternative that would avoid this distortion would be to transform the child care subsidy into a lump-sum transfer to families with small children, conditional on both parents working a significant number of work hours. Such a policy would provide the same incentives to work but would not distort the consumption mix.

Were the current child care subsidy, which is about 85,000 SEK per child and per year (slightly less than one-third of the median income), instead distributed as a check to eligible families, they could spend this transfer

8. Since the 2001 reform, unemployed workers have had limited access to child care (fifteen hours per week).

9. As our model analysis reveals, the incentives to choose work hours for those already working will be different if we compare the Swedish child care subsidy with an in-work benefit of the EITC type. This is a consequence of differences in how they are constructed in terms of income indexation of the benefit. 
on market-purchased child care or solve their child care problems through flexible work times, relatives, or some other way, so they could instead use this transfer for consumption of other goods and services. While this is a policy worth considering, it is not without its own potential distortions. For example, publicly provided high-quality child care can be viewed as education, which has potentially positive externalities.

\section{Appendix}

\section{A Model of Female Work Behavior: The Case of Paid Parental Leave}

In this appendix, we build a basic model to study the effects on female career choices and incomes of the two daddy-month reforms. Available for download at: http://people.su.se/ akolm/, you will also find the formal analysis of the other policy reforms considered in this chapter.

The basic model is set in two periods. In the first period, women are married, whereas in the second period, there is an exogenous probability, $1-$ $p$, that the marriage will be dissolved. At the beginning of the first period, the woman makes her career choice. By allocating her available time into market work, $L_{M}$, and family work, $L_{H}$, she can decide how much of a marketoriented career and how much of a family-oriented career she wants to make. As the allocation of time also has consequences for the future, she allows for the future possibility that the marriage will dissolve when making her time allocation decision. The payoff from investing in market work is given by the net wage income, $w L_{M}-T\left(w L_{M} ;.\right)$, where $w$ is the wage, and $T\left(w L_{M} ;.\right)$ is the tax payments. The tax schedule is $T\left(w L_{M} ;.\right)=B\left(w L_{M}\right)^{2}-A$, where $A$ and $B$ are parameters.

Women derive utility from material good consumption, $C$, and from the consumption of a family good, $F$, which we interpret here as care for children. The family good can be produced/consumed at home by the mother, $F_{H}$, or by the father, $\bar{F}$, or it can be purchased in the market, $F_{M}$, where these are perceived to be perfect substitutes; that is, $F=F_{M}+F_{H}+\bar{F}$. The mother produces the family good by use of own time, $L_{H}$, through the concave production function $F_{H}=L_{H}^{\alpha}, \alpha<1 .{ }^{10}$ The payoff from investing time in the family is the utility the care time yields.

The financial aspect of the paid parental leave is allowed for by adding a proportional subsidy for each time unit allocated to family activity in the first period. The derived utility of the first period is $v(F)+w L_{M}-$

10. It does not matter for the results that $\bar{F}$ is introduced as linear in father's time, although the woman's time enters through a concave function. Moreover, it does not affect the results if we assume that $F_{M}=L_{M}-\bar{F}$; that is, if we assume that the demand for child care has to be equal to the time when no one is at home. 
$B\left(w L_{M}\right)^{2}+A-k F_{M}+S\left(L_{H} ;.\right)$, where $v(F)$ captures the utility from care for children, and $w L_{M}-B\left(w L_{M}\right)^{2}+A-k F_{M}+S\left(L_{H} ;\right.$.) captures the utility from material good consumption. Material good consumption is simply given by the income net of taxes and the payment from paid parental leave, $S\left(L_{H}\right.$; ), subtracting the expenses for market-purchased child care, $k F_{M}$, where $k$ is the price of market-purchased care for children. The payment from paid parental leave is given by $S\left(L_{H} ;.\right)=s L_{H}$ if $L_{H} \leq \bar{L}_{H}$, and $S\left(L_{H} ;\right.$; $)=s \bar{L}_{H}$ if $L_{H}>\bar{L}_{H}$. Thus, if staying home with children more hours than $\bar{L}_{H}$, then the ceiling of the paid parental leave is reached. The female spouse cannot then reap more paid parental leave by increasing her family time.

In the second period, the children are older (possibly grown-up), and the utility is simply given by the income net of taxes, which is used for material good consumption, $w L_{M}-B\left(w L_{M}\right)^{2}+A$. Imposing the time constraint, $\bar{T}=$ $L_{M}+L_{H}$, and ignoring discounting, the expected present value can be written:

$$
\begin{aligned}
E V= & v\left[F_{M}+\bar{F}+\left(\bar{T}-L_{M}\right)^{\alpha}\right]+2 w L_{M} \\
& -2 B\left(w L_{M}\right)^{2}+2 A-k F_{M}+S\left(\bar{T}-L_{M} ;\right) .
\end{aligned}
$$

The female spouse chooses both the time allocation and how much of the family good she wants to purchase from the market in order to maximize the expected present value. For an interior solution, $L_{M}, L_{H} \in(0, \bar{T})$ and $F_{M}>0$, the following first-order conditions determine the optimal choices: ${ }^{11}$

$$
\begin{aligned}
& \frac{\partial E V}{\partial L_{M}}=-v^{\prime}(F) \alpha\left(\bar{T}-L_{M}\right)^{\alpha-1}+2 w-4 B w^{2} L_{M}-S^{\prime}\left(\bar{T}-L_{M} ; .\right)=0 \\
& \frac{\partial E V}{\partial F_{M}}=v^{\prime}(F)-k=0,
\end{aligned}
$$

where $S^{\prime}\left(L_{H} ;.\right)=s$ if $L_{M}>\bar{L}_{M}$, and $S^{\prime}\left(L_{H} ;.\right)=0$ if $L_{M} \leq \bar{L}_{M}$.

The objective function is continuous but has a kink point at $L_{M}=\bar{L}_{M}$ in the presence of the paid parental leave system. We have to consider both cases: when female spouses choose to exhaust their periods of paid parental leave, $L_{M} \leq \bar{L}_{M}$, and when they do not use all of the periods of paid parental leave they are entitled to, $L_{M}>\bar{L}_{M}$.

The government budget constraint is fulfilled at all times by allowing for adjustments in the parameter $B$ :

$$
2\left[B L_{M}^{2}-A\right]=\delta\left[S\left(\bar{T}-L_{M} ; .\right)+\mathrm{s} \bar{F}\right],
$$

where $\delta \in[0,1]$ captures the share of the government expenditures that is financed by the female workers. 


\section{The Daddy Months}

In 1995, the first daddy month was introduced. The reform implied that one month of the paid parental leave must be used by each parent. In practice, it meant that fathers could no longer transfer all their paid parental leave to the mother. Unless at least one month was used by the father, it could not be used by either of the parents. In 2002, the second daddy month was implemented. The reform reserved two months for each parent. At the same time, the total time of entitlement to paid parental leave for the family increased by thirty days. In essence, this implied that an extra month available only for fathers was added to the existing paid parental leave scheme.

We represent these two types of reforms by letting $\bar{F}$ increase. By increasing $\bar{F}$, we increase the father's family time. In a reform similar to the 2002 reform, this will have no impact on the mother's available time for paid leave, $\bar{L}_{M}$. The results are as follows:

Proposition A1: Increased paid family time of fathers, $\bar{F}$, will reduce or have no impact on women's investment in a market career and will increase poverty among divorced women.

PROOF: All propositions follow from the differentiation of the first-order conditions and the government budget constraint. Poverty among divorced women, for simplicity, is measured by the disposable income of divorced women. The welfare gap is measured by the utility difference of married and divorced women.

An increase in the father's time at home initially induces the mother to reduce the market-purchased care time by an equivalent amount. However, as the reform is financed by increased taxation, the mother finds it optimal to work less and instead spends more time at home (reducing her market purchase of care time even more). The reform thus induces mothers to stay home longer with their children in response to fathers increasing their parental leave time. Poverty among divorced women increases, both because they choose to invest less in a market career, and because the reform induces tax increases.

Also, if women bunch at the kink point (i.e., $L_{M}=\bar{L}_{M}$ ), the required tax increases will reduce the incentives to work. However, the budget effect may not be strong enough to counteract the bunching at the kink point.

When considering the 1995 reform, we have to allow for the fact that this reform implies that $L_{M}$ falls by an equivalent amount, leaving the family's total time of paid parental leave periods intact. The results are as follows:

Proposition A2: Increased paid family time of fathers. $\bar{F}$, leaving the total time of paid parental leave intact, will (a) leave women's investment in market work and poverty among divorced women unaffected if women allocate more time to the family than the paid leave pays for; (b) reduce women's investment 
in market work and increase poverty among divorced women if women do not exhaust their periods of paid parental leave; or (c) increase women's investment in market work and reduce poverty among divorced women if women bunch at the kink point.

In case women take more leave than the system pays for, there is no need to increase taxes in order to finance the reform. The reform is self-financed, as the lump-sum parental leave payments to women are reduced by the same amount as the cost of financing a longer paid parental leave for fathers. Therefore, the career choices and economic situation of divorced women are unaffected.

On the other hand, in case women do not exhaust their periods of paid parental leave, the reduction in $\bar{L}_{M}$ has no effect on women's investment in a market career. Thus, the analyses of the previous proposition hold.

In case the father's paid family time increases in a situation where women bunch at the kink point, female investment in a market-oriented career will increase. Women who choose exactly to exhaust their periods of paid parental leave face a reduction in the marginal cost of working when their available periods of paid leave are reduced. This follows because increased working time is no longer associated with a reduction in the benefits of paid parental leave. Thus, the incentive to invest in a more market-oriented career has improved, which also improves the economic situation of divorced women.

\section{References}

Albrecht, J., P.-A. Edin, and S. Vroman. 1999. Career interruptions and subsequent wages: A reexamination using Swedish data. Journal of Human Resources 34 (2): 294-311.

Andrén, T. 2003. The choice of paid childcare, welfare, and labor supply of single mothers. Labour Economics 10 (2): 133-47.

Bergemann, A., and G. J. van den Berg. 2006. From childbirth to paid work: A structural analysis of the effects of adult education on labor market outcomes of prime-aged mothers. Paper presented at the European Cooperation in Science and Technology (COST) A23 meeting. 19-20 October, Essen, Germany.

Boeri, T., D. Del Boca, and C. Pissarides, eds. 2005. Women at work: An economic perspective. Oxford: Oxford University Press.

Datta Gupta, N., N. Smith, and M. Verner. 2006. Child care and parental leave in the Nordic countries: A model to aspire to? IZA Discussion Paper no. 2014. Bonn, Germany: Institute for the Study of Labor, March.

Del Boca, D., and S. Pasqua. 2005. Labor supply and fertility in Europe and the US. In Women at work: An economic perspective, ed. T. Boeri, D. Del Boca, and C. Pissarides, 125-54. Oxford: Oxford University Press.

Domeij, D., and P. Klein. 2008. Should daycare be subsidized? Manuscript, February. Available at: http://www.eco.uc3m.es/temp/agenda/mothers080214.pdf. 
Eissa, N., and H. Hoynes. 2004. Taxes and the labor market participation of married couples: The earned income tax credit. Journal of Public Economics 88 (9/10): 1931-58.

2006. Behavioral responses to taxes: Lessons from the EITC and labor supply. In Tax policy and the economy, vol. 20, ed. J. M. Poterba, 73-110. Cambridge, MA: National Bureau of Economic Research.

Eissa, N., and J. Liebman. 1996. Labor supply response to the earned income tax credit. Quarterly Journal of Economics 111 (2): 605-37.

Ekberg, J., R. Eriksson, and G. Friebel. 2005. Parental leave: A policy evaluation of the Swedish "daddy-month" reform. IZA Discussion Paper no. 1617. Bonn, Germany: Institute for the Study of Labor, May.

Eriksson, R. 2005. Parental leave in Sweden: The effects of the second daddy month. SOFI Working Paper no. 9/2005. Stockholm University, Swedish Institute for Social Research, December.

Flood, L., J. Hansen, and R. Wahlberg. 2004. Household labor supply and welfare participation in Sweden. Journal of Human Resources 39 (4): 1008-32.

Flood, L., E. Pylkkänen, and R. Wahlberg. 2007. From welfare to work: Evaluating a proposed tax and benefit reform targeted at single mothers in Sweden. Labour 21 (3): 443-71.

Freeman, R., and R. Schettkat. 2005. Marketization of household production and the EU-US gap in work. Economic Policy 20 (41): 5-50.

Jaumotte, F. 2003. Female labour force participation: Past trends and main determinants in OECD countries. OECD Economics Department Working Paper no. 376. Paris: Organization for Economic Cooperation and Development.

Kennerberg, L. 2007. Hur förändras kvinnors och mäns arbetssituation när de får barn? IFAU Rapport no. 2007:9. Uppsala, Sweden: Institute for Labor Market Policy Evaluation.

Kleven, H. 2004. Optimum taxation and the allocation of time. Journal of Public Economics 88 (3/4): 545-57.

Kolm, A.-S. 2008. Comment on Bruce Meyer: The earned income tax credit-A Swedish perspective. Swedish Economic Policy Review 14 (2): 81-85.

Lundin, D., E. Mörk, and B. Öckert. 2007. Maxtaxan inom barnomsorgenPåverkar den hur mycket föräldrar arbetar? IFAU Rapport no. 2007:2. Uppsala, Sweden: Institute for Labor Market Policy Evaluation.

Meyer, B., and D. Rosenbaum. 2001. Welfare, the earned income tax credit and the labor supply of single mothers. Quarterly Journal of Economics 116 (3): 1063-114.

Nyberg, A. 2005. Har den ekonomiska jämställdheten ökat sedan början av 1990talet? Makt att forma samhället och sitt eget liv_ jämställdhetspolitiken mot nya mål. SOU 2005:66 Forskarrapporter. Stockholm: Swedish Government Official Reports.

Pylkkänen, E., and N. Smith. 2004. The impact of family-friendly policies in Denmark and Sweden on Mothers' career interruptions due to childbirth. IZA Discussion Paper no. 1050. Bonn, Germany: Institute for the Study of Labor, March.

Ronsen, M., and M. Sundström. 2002. Family policy and after-birth employment among new mothers. European Journal of Population 18 (2): 121-52.

Rosen, S. 1997. Public employment, taxes, and the welfare state in Sweden. In The welfare state in transition: Reforming the Swedish model, ed. R. B. Freeman, H. Topel, and B. Swedenborg, 79-109. Chicago: University of Chicago Press.

Ruhm, C. 1998. The economic consequences of parental leave mandates: Lessons from Europe. Quarterly Journal of Economics 113 (1): 285-317.

Simonsen, M. 2005. Availability and price of high quality child care and female 
employment. Working Paper no. 2005-8. University of Aarhus, School of Economics and Management, May.

Sorensen, P. B. 1997. Public finance solutions to the European unemployment problem? Economic Policy 12 (25): 223-64.

Westerlund, L., J. Lindblad, and M. Larsson. 2005. Föräldraledighet och arbetstid: hur mycket jobbar föräldrar som varit hemma med barn. LO Rapport. Stockholm: Landsorganisationen i Sverige. 